\title{
Reservoir characteristics and control mechanism of resistivity low-contrast oil pays in Chang 8 tight sandstone of Longdong West area, Ordos Basin
}

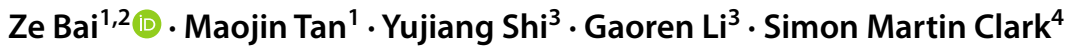

Received: 8 February 2021 / Accepted: 24 May 2021 / Published online: 11 June 2021

(C) The Author(s) 2021

\begin{abstract}
Log interpretation and evaluation of tight sandstone reservoir in Chang 8 Member of Longdong West area, Ordos Basin, China, are facing great challenges due to the co-development of normal oil pay and resistivity low-contrast oil pay. To better guide the exploration and development of oil resources in this area, the reservoir characteristics and control mechanism of resistivity low-contrast oil pay were studied. Firstly, the reservoirs were divided into resistivity low-contrast oil pay (RLP) and normal oil pay (NP) based on the relative value of the apparent resistivity increase rate. Then, the difference of reservoir characteristics between RLP and NP is analyzed by comparing a series of experimental data and real logging data in those two reservoir types. Finally, the control mechanism of RLP was studied from reservoir micro-factors and regional macrofactors, respectively. It is found that the chlorite and illite are the most abundant clay minerals in RLP and NP, respectively. Compared with NP reservoir, the average porosity of RLP is better, but the pore space is mainly composed of micropores, which lead to smaller average pore throat radius and poor pore structure. The high irreducible water saturation and high formation water salinity reduced the reservoir resistivity from micro-aspect. Besides, the difference of hydrocarbon expulsion capacity of source rock and the regional difference of formation water salinity controlled the distribution of RLP and NP. Comprehensive consideration of the reservoir micro-factors and regional macro-factors is important to carry out effective logging interpretation and evaluation.
\end{abstract}

Keywords Tight sandstone $\cdot$ Resistivity low-contrast oil pay $\cdot$ Reservoir characteristic $\cdot$ Control mechanism $\cdot$ Longdong west area

\section{Introduction}

Resistivity low-contrast oil pay, as an important oil resources with strong concealment, has received much interest in recent years due to their high oil production and wide

\section{Ze Bai}

baize@aust.edu.cn

1 School of Geophysics and Information Technology, China University of Geosciences, Beijing 100083, China

2 School of Earth and Environment, Anhui University of Science and Technology, Huainan 232001, China

3 A Research Institute of Exploration and Development, PetroChina Changqing Oilfield Company, Xi' an 710018, China

4 Department of Earth and Planetary Sciences, Macquarie University, Sydney, NSW 2109, Australia distribution around the world (Zemanek 1989; Worthington 2000; Onyinye 2010). The resistivity low-contrast oil pay is defined as an oil zone which has small resistivity difference to the water layer, and it can be summarized into two aspects: (1) The absolute value of resistivity in oil layers is low, which can be lower than that of adjacent water layers. (2) The resistivity increase rate of the oil layer is generally between 1.0 and 3.0 (Xie et al. 2002; Ouyang et al. 2009; Zhang et al. 2018). This phenomenon makes it difficult to distinguish oil pays from water layers by using resistivity logging response (Chu and Steckhan 2011; Xiao et al. 2012).

The problem for the log interpretation and evaluation of resistivity low-contrast oil pay has existed for many years because of its complicated genesis and conductive mechanism (Etnyre and Mullarkey 1996; Kumar et al. 2009). Up till now, there are more than ten known factors that lead to resistivity low-contrast oil pay reservoirs, such as shoulder bed effects, irreducible water, conductive minerals, clay types and their 
contents, pore structure, wettability, formation water salinity and drilling mud invasion (Yang et al. 2008; Claverie et al. 2010; Qin et al. 2013; William et al. 2016). Yan et al. (2018) classified these influential factors into two categories, including internal factors related to reservoir properties and external factors affected by external conditions. Generally, the resistivity low-contrast oil pay is usually caused by the combining influence of several factors, and the main influence factors are often controlled by the geological characteristics of the reservoir, so that there is not a unified standard for understanding the genesis of resistivity low-contrast oil pay reservoirs in different oilfields and research institutes(Hamada and Al-Awad 2000; Montaron 2007; Kibria and Hossain 2012; Feng et al. 2017b). However, there is a law to follow for the resistivity low-contrast oil pay in a certain area or a certain type of specific reservoir (Yan et al. 2010; Mao 2016). On the basis of reservoir characteristics analysis, studying the main influence factors of resistivity low-contrast oil pay from multiple aspects is the key to carry out effective log interpretation and evaluation (Mao et al. 2007; Ayham et al. 2016; Pratama et al. 2017). Kusuma et al. (2016) proposed an effective method to identify resistivity low-contrast oil pay zones during the re-evaluation of old wells in the " $\mathrm{S}$ " field by integrated analysis of the main factors causing the low resistivity zones. Arbab et al. (2017) established a reliable water saturation model based on the pore structure characteristics of resistivity low-contrast oil pay in carbonate reservoir of Buwaib Formation in the Persian Gulf. Bai et al. (2019) proposed a comprehensive fluid identification method for fluid typing in the Huanxian area of the Ordos Basin in China by analyzing the regional distribution characteristics of resistivity low-contrast oil pay reservoir.

The tight sandstone reservoir in Longdong West area, Ordos Basin, China, is exploring and developing. The target bed of this study is Chang 8 tight sandstone reservoir, which is located below the Chang 7 oil shale, and it is the main production horizon of oil and gas in this area due to its good hydrocarbon storage condition (Fig. 1). However, with the deepening of oil exploration and development, more and more resistivity low-contrast oil pays were found, which brings great difficulties to the log interpretation and evaluation of reservoir. Therefore, we present a research to study the reservoir characteristics and control mechanism of resistivity low-contrast oil pay, which aim to provide a valuable reference for the future exploration and development of resistivity low-contrast oil pays in this area.

\section{Data and research method}

Considering that the resistivity low-contrast oil pay and normal oil pay are developed together in this region, so we first separated the reservoir into resistivity low-contrast oil pay (RLP) and normal oil pay (NP) based on the relative value of the apparent resistivity increase rate (ARI), which is calculated by dividing the log data of formation resistivity (RT) by the pure water layer $\left(\mathrm{R}_{0}\right)$ of the same or adjacent well sections. According to the previous understanding of the definition of RLP reservoir (Xie et al. 2002; Ouyang et al. 2009; Zhang et al. 2018), we take the oil pay reservoir with ARI less than 3 as RLP, and the oil pay reservoir with ARI greater than 3 as NP. Then, the reservoir rock composition, porosity and permeability, pore structure and logging response characteristics were analyzed by comparing the experimental data and real logging data collected from these two reservoir types. Finally, the control mechanism of RLP was studied from the micro-factors and macro-factors, respectively. Among them, the micro-factors include the reservoir irreducible water saturation and formation water salinity. And the macro-factors include the hydrocarbon expulsion capacity of source rock and the regional difference of formation water salinity. Figure 2 shows the flowchart of the whole research method.

\section{Results and discussion}

\section{Reservoir characteristics analysis}

\section{Rock composition}

Figure 3 shows the ternary diagrams of the reservoir rock composition in RLP and NP reservoir based on the XRD whole-rock analysis result. It can be seen that the reservoir rock composition of RLP and NP is basically the same, and the rock lithology is mainly lithic arkoses and feldspathic litharenites. The content of interstitial materials in the rock pores is high, and the components are mainly authigenic clay minerals. According to the XRD clay fraction mineralogy analysis, results show that the main types of authigenic clay minerals are chlorite and illite, among which the chlorite is the most abundant in RLP (ave. 50.1\%), and illite is the most abundant clay mineral in NP (ave. 39.7\%). But the content of illite-smectite mixed layer with strong cation exchange capacity is not high, less than $15 \%$ of the total amount of clay minerals (Fig. 4a). Based on the experimental data of clay cation exchange capacity of 8 cores from RLP and 6 cores from NP, the relationship between clay cation exchange capacity of reservoir and log resistivity is established (Fig. 4b). It can be seen that the clay cation exchange capacity of RLP in our study area is less than $2 \mathrm{mmol} / 100 \mathrm{~g}$, and the effect of clay cation exchange capacity on reservoir resistivity is not significant.

\section{Porosity and permeability}

Figure 5 shows the distribution frequency histogram based on the overburden porosity and permeability measurement 

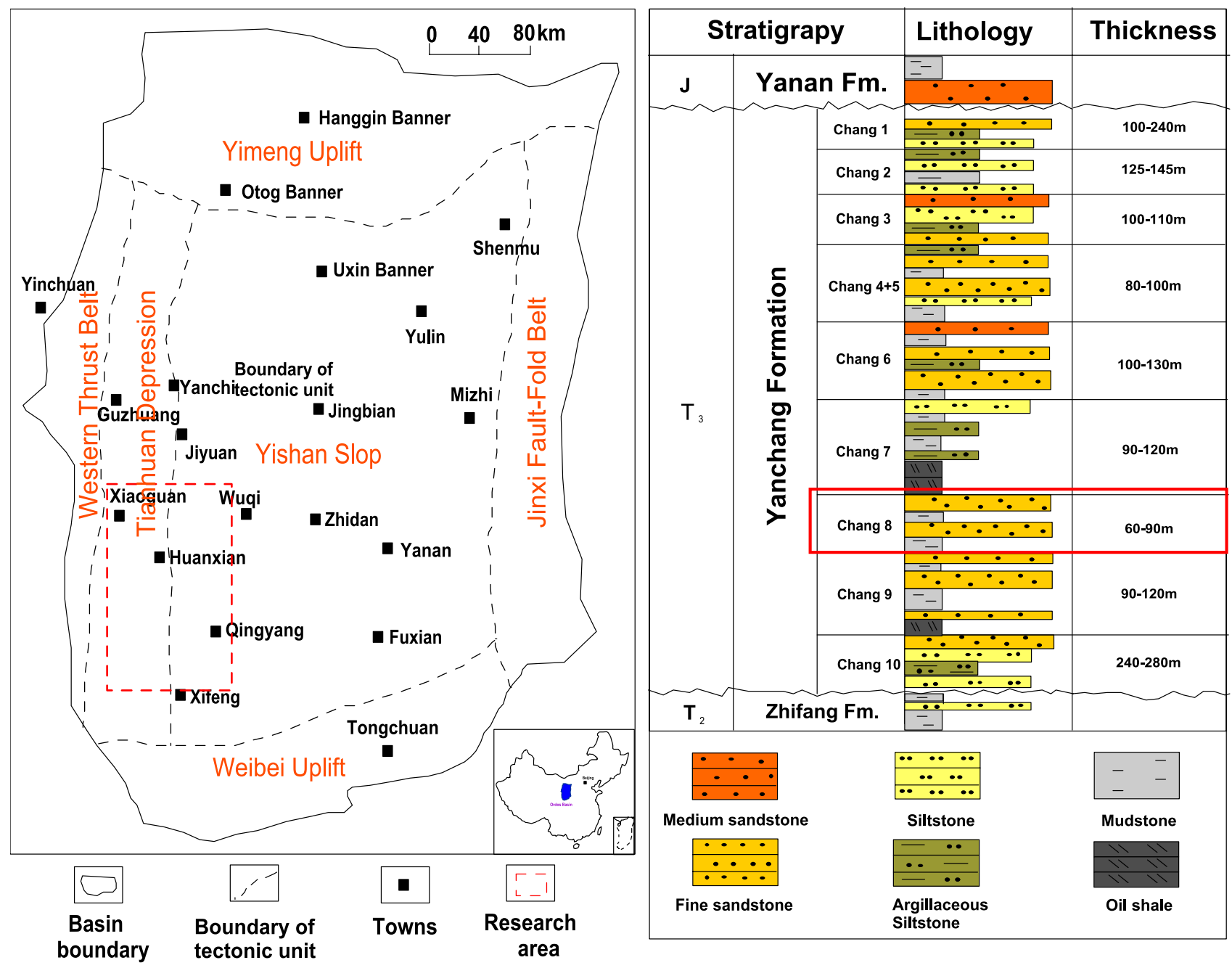

Fig. 1 Location of the research area and target horizon

results of 35 cores from RLP and 40 cores from NP. It can be seen that the porosity of RLP is mainly distributed between 8 and 12\%, with an average of $10.43 \%$. And the permeability is mainly distributed between 0.001 and $0.3 \mathrm{mD}$, with an average of $0.2 \mathrm{mD}$. The porosity of NP reservoir is mainly distributed between 4 and $10 \%$, with an average of $7.01 \%$. And the permeability is mainly distributed between 0.001 and $0.3 \mathrm{mD}$, with an average of $0.16 \mathrm{mD}$. According to the cross-plot of porosity and permeability, the porosity and permeability meet a good power index relationship, and the curve slope of the fitting relationship between porosity and permeability of RLP reservoir is lower than that of NP reservoir (Fig. 6). That is to say, although the average porosity and permeability of RLP reservoir are better than that of NP reservoir, the permeability of RLP reservoir will be lower than that of NP reservoir under the same porosity.

\section{Pore structure characteristics}

Figure 7 shows the intrusive mercury curve obtained from the core mercury injection experiment of RLP and NP. The mercury injection curve can be divided into three stages from its shape characteristic: initial mercury injection stage, intermediate platform stage and final rising stage, which correspond to the mercury intrusion process from macro-pores to micropores. The pressure corresponding to the initial stage of mercury injection is called displacement pressure $\left(\mathrm{P}_{\mathrm{d}}\right)$. The smaller the displacement pressure is, the more easily mercury enters the macro-pores. Figure 8 shows the distribution characteristics of NMR $\mathrm{T}_{2}$ spectrum in RLP and NP. In general, the pore size is related to the distribution range of $\mathrm{T}_{2}$ spectrum, macropores component corresponds to the longer $\mathrm{T}_{2}$ relaxation time, and the micropores component corresponds to the 


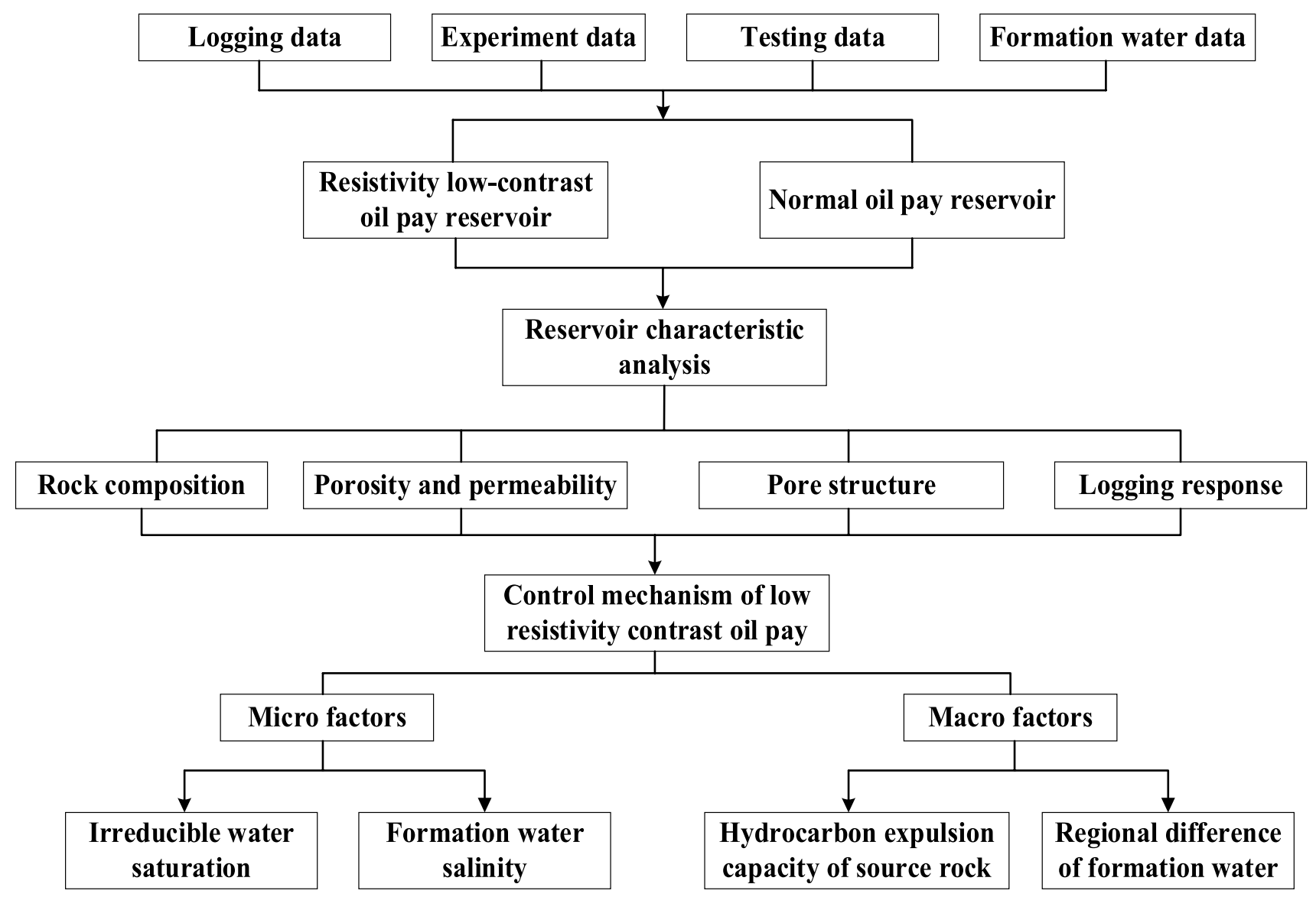

Fig. 2 Flowchart for the research

Fig. 3 Ternary diagram of rock composition: a RLP reservoir (61 core samples) and b NP reservoir (128 core samples). Notes: Q: quartz; F: feldspar; R: rock fragments

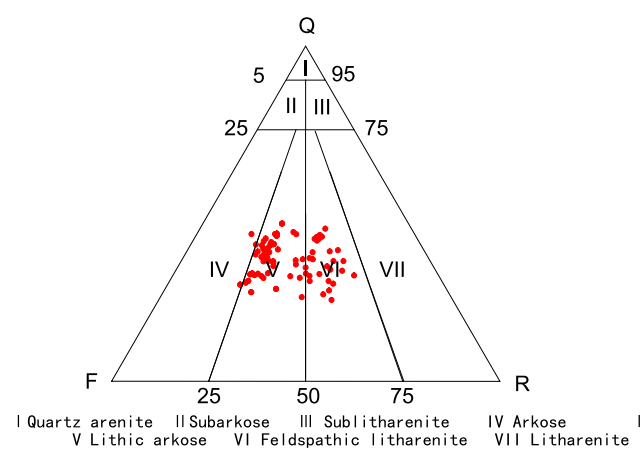

(a)

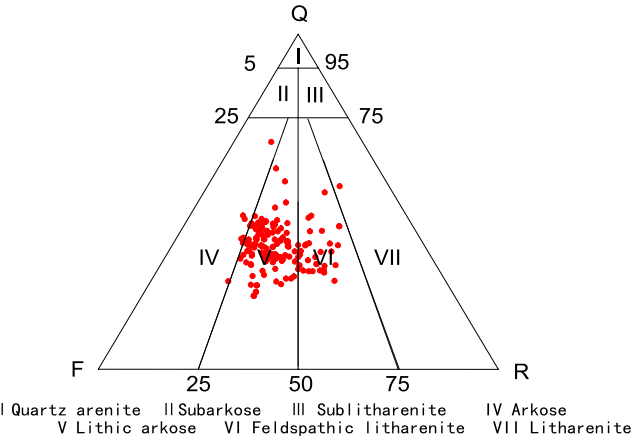

(b) shorter $\mathrm{T}_{2}$ relaxation time. The sum of $\mathrm{T}_{2}$ spectrum amplitude reflects the porosity of the core. The pore structure parameters calculated by MICP and NMR experiments are shown in Table 1. It can be seen that the NMR porosity of RLP is higher than that of NP (ave. $10.4 \%$ and ave. $7.05 \%$, respectively), the $\mathrm{T}_{2}$ geometric average value $\left(\mathrm{T}_{2 \mathrm{gm}}\right)$ and the average pore throat radius $\left(\mathrm{R}_{\text {ave }}\right)$ of RLP are smaller, and the displacement pressure $\left(\mathrm{P}_{\mathrm{d}}\right)$ is larger. Besides, the maximum mercury saturation $\left(\mathrm{S}_{\mathrm{Hg}}\right)$ of RLP reservoir is higher than that of NP reservoir $(89.02 \%$ and $77.75 \%$, respectively). These indicate that although the porosity of RLP is higher, the pore space is mainly composed of micropores, which lead to the smaller average pore throat radius and poor pore structure. When the oil filling pressure is high enough, high oil saturation can be formed in RLP reservoir. 
Fig. 4 a The distribution of different interstitial materials in RLP and NP from XRD clay fraction mineralogy analysis; b the relationship between the clay cation exchange capacity and reservoir resistivity

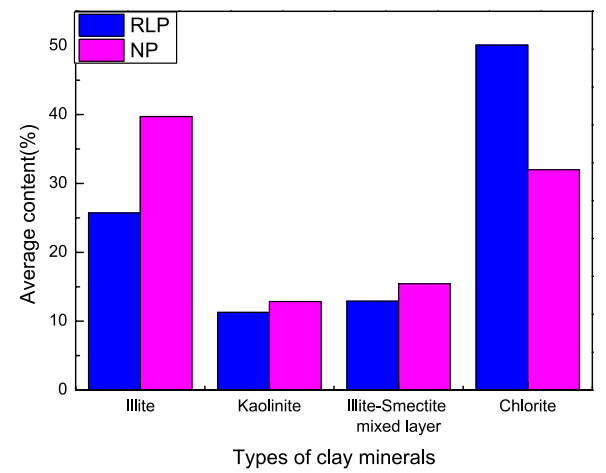

(a)

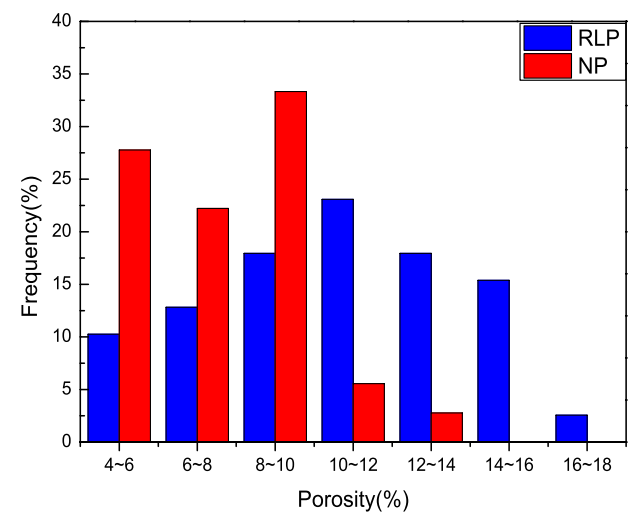

(a)

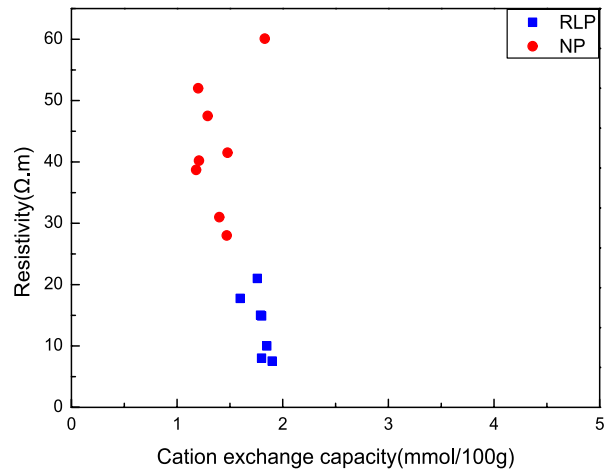

(b)

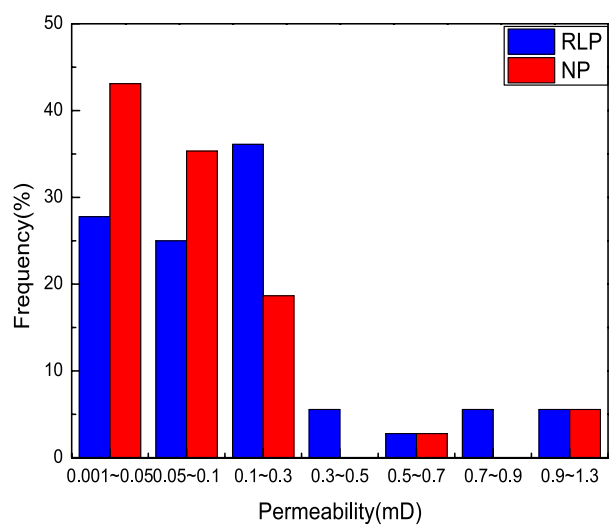

(b)

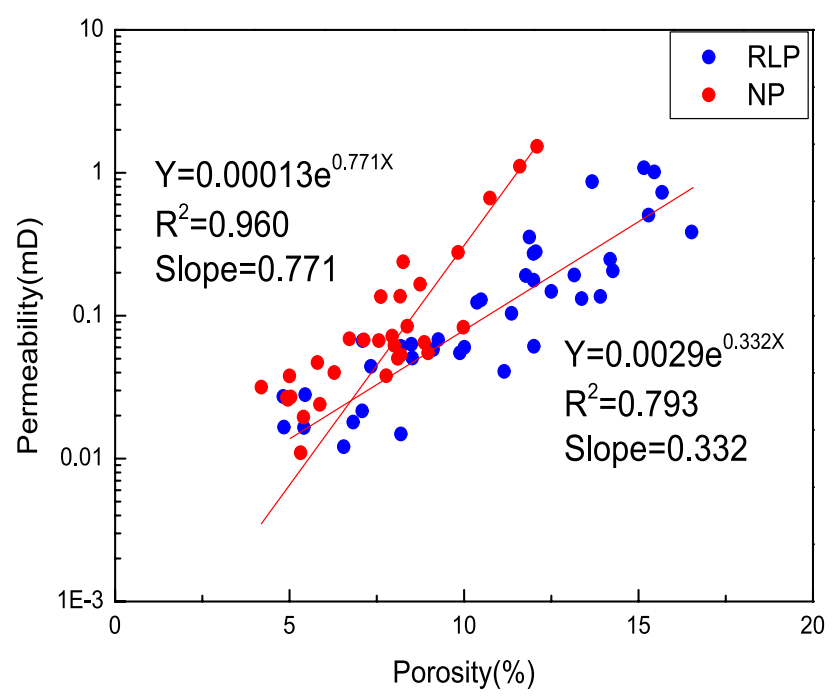

Fig. 6 The relationship between porosity and permeability

\section{Logging response characteristics}

Logging response is the comprehensive reflection of physical properties and oil-bearing properties of reservoir rocks, and it is the most direct and effective data to understand reservoir characteristics (Tan, 2020). According to the logging response and formation testing results of reservoir, the cross-plot of density and resistivity of different fluid types is drawn in Fig. 9. It can be seen that with the increase in reservoir density, the reservoir resistivity increases gradually. And it is difficult to identify the RLP layer from water layer by the difference of density and resistivity. Table 2 shows the logging response characteristics of different fluid types by analyzing the logging response of 13 RLP formations and $20 \mathrm{NP}$ formations and their adjacent wells. It can be seen that the difference of relative shale content $(\Delta \mathrm{GR})$ between RLP reservoir and NP reservoir is small, which indicates that the influence of reservoir shale content on resistivity is not obvious. However, the relative amplitude of spontaneous potential $(\Delta \mathrm{SP})$ of RLP reservoir is higher than NP reservoir, and with the improvement of oil-bearing, the value of $\Delta \mathrm{SP}$ decreases gradually, which reflects that the water property is likely to be an important reason for the change of electrical property.

On the basis of the above analysis of reservoir characteristics, the control mechanism of RLP was studied and summarized into two aspects: One is micro-reservoir factors, 
Fig. 7 The characteristics of mercury injection curve of a RLP reservoir and $\mathbf{b} \mathrm{NP}$ reservoir
Fig. 8 The distribution characteristics of NMR $\mathrm{T}_{2}$ spectrum of a RLP reservoir and $\mathbf{b} \mathrm{NP}$ reservoir
Table 1 The pore structure parameters calculated from MICP and NMR experiments

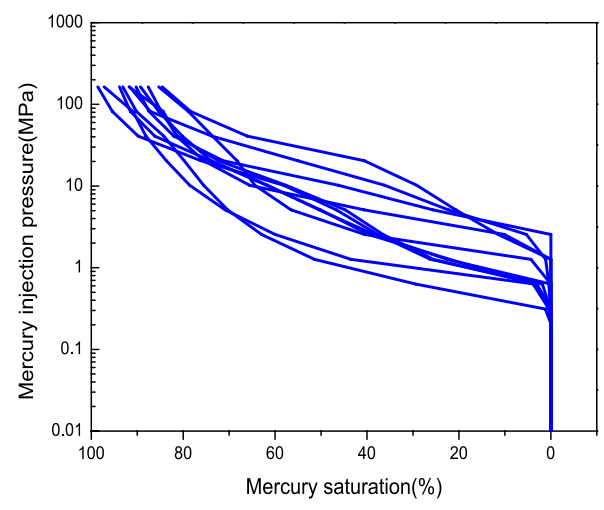

(a)

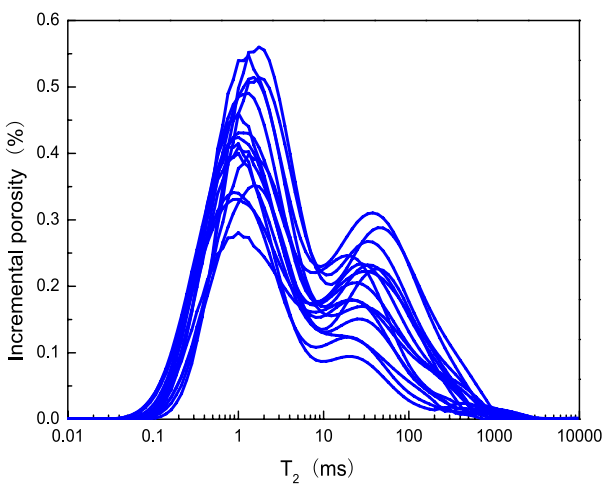

(a)

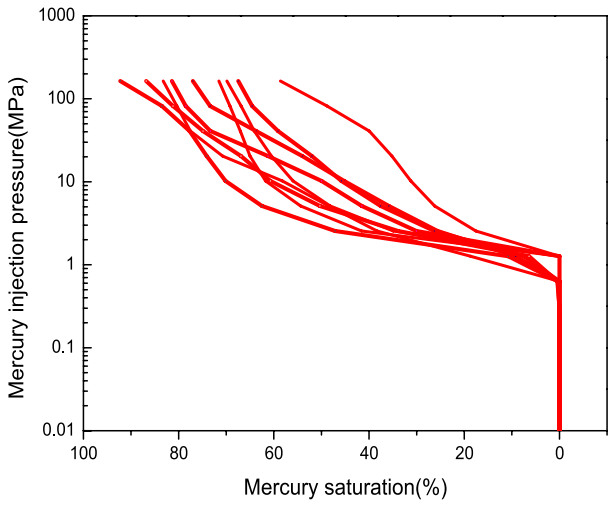

(b)

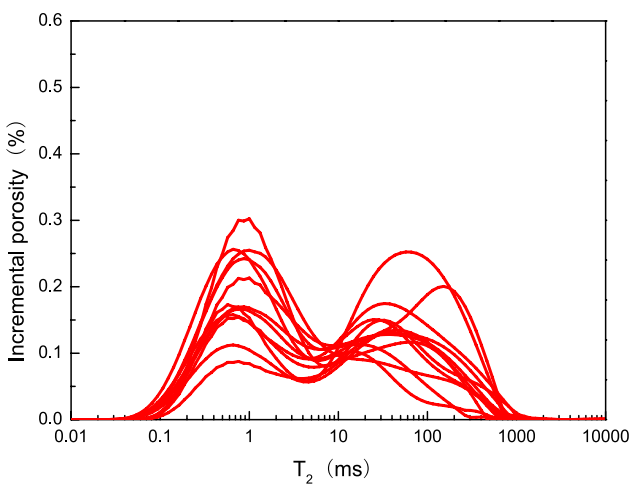

(b)

\begin{tabular}{|c|c|c|c|c|c|c|c|c|c|c|}
\hline \multirow[t]{2}{*}{ Type } & \multicolumn{2}{|c|}{ NMR POR(\%) } & \multicolumn{2}{|c|}{$\mathrm{NMR} \mathrm{T}_{2 \mathrm{gm}}(\mathrm{ms})$} & \multicolumn{2}{|l|}{$\mathrm{P}_{\mathrm{d}}(\mathrm{MPa})$} & \multicolumn{2}{|l|}{$\mathrm{R}_{\mathrm{ave}}(\mathrm{um})$} & \multicolumn{2}{|l|}{$\mathrm{S}_{\mathrm{Hg}}(\%)$} \\
\hline & Range & Ave & Range & Ave & Range & Ave & Range & Ave & Range & Ave \\
\hline RLP & $8.4-15.6$ & 10.4 & $1.3-5.8$ & 4.78 & $0.31-2.55$ & 1.12 & $0.02-0.7$ & 0.19 & $77-98.5$ & 89.02 \\
\hline NP & $4.95-9.6$ & 7.05 & $1.9-8.9$ & 6.99 & $0.63-1.26$ & 0.82 & $0.07-0.7$ & 0.27 & $69.8-91.7$ & 77.75 \\
\hline
\end{tabular}

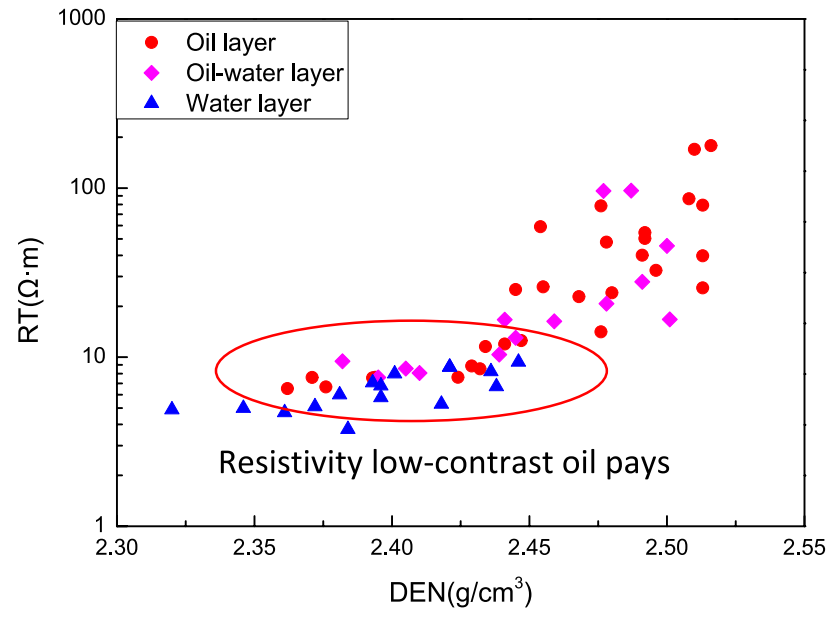

Fig. 9 The cross-plot of density (DEN) and resistivity (RT) of different fluid types including the influence of irreducible water saturation and formation water salinity on formation resistivity; the other is regional macro-factors, including the influence of hydrocarbon expulsion capacity of source rock and the regional difference of formation water salinity on the distribution of RLP.

\section{Control mechanism of RLP reservoir}

\section{Micro-factors: irreducible water saturation}

According to the scanning electron microscope (SEM) analysis results, the main clay minerals of chlorite and illite mainly fill the pores in the form of thin film and filamentous, which is easy to adsorb and form bound water (Fig. 10). Meanwhile, the micropores are filled with bound water, which easily leads to high irreducible water saturation $\left(\mathrm{S}_{\mathrm{wi}}\right)$. 
Based on the calculation and statistics results of nuclear magnetic resonance $S_{w i}$ of 14 cores from RLP reservoir and 12 cores from NP reservoir, it is found that the $S_{w i}$ of RLP is generally higher than that of NP. The irreducible water saturation of RLP is mainly distributed in $40-70 \%$, with an average value of $64.2 \%$, while the irreducible water saturation of NP is mainly distributed between 30 and 50\%, with an average value of $45.7 \%$ (Fig. 11a). The relationship between apparent resistivity increase rate (ARI) and irreducible water saturation is plotted in Fig. 11b. It can be seen that with the increase in irreducible water saturation, the formation resistivity increase rate decreases gradually. When the irreducible water saturation increases to nearly $45 \%$, the API is less than 3, which indicates that high irreducible water saturation reduced the resistivity contrast between water layer and oil layer.

\section{Micro-factors: formation water salinity}

As the main conductive medium in pore space of rock, the salinity of formation water also affects the reservoir resistivity logging response. According to the statistical results of formation water analysis data of production well adjacent to RLP layer and NP layer, the formation water salinity varies greatly and the salt is mainly calcium chloride (Table 3). The formation water salinity in the NP is
Table 2 Logging response characteristics of different fluid types

Fig. 10 SEM observation: a chlorite mainly fills the pores in the form of thin film, and $\mathbf{b}$ illite mainly fills the pores in the form of filamentous. (CF: chlorite film; FI: filamentous illite)

\begin{tabular}{|c|c|c|c|c|c|c|c|c|c|}
\hline \multirow[t]{2}{*}{ Types } & \multirow[t]{2}{*}{ Fluid types } & \multicolumn{2}{|c|}{$\operatorname{DEN}\left(\mathrm{g} / \mathrm{cm}^{3}\right)$} & \multicolumn{2}{|l|}{$\Delta \mathrm{GR}$} & \multicolumn{2}{|c|}{$\Delta \mathrm{SP}(\mathrm{mV})$} & \multicolumn{2}{|l|}{$\mathrm{RT}(\Omega \cdot \mathrm{m})$} \\
\hline & & Range & Ave & Range & Ave & Range & Ave & Range & Ave \\
\hline \multirow[t]{3}{*}{ RLP } & Oil layer & $2.37-2.52$ & 2.38 & $0.1-0.34$ & 0.24 & $0.5-0.94$ & 0.70 & $6.44-22.5$ & 11.65 \\
\hline & Oil-water layer & $2.39-2.49$ & 2.42 & $0.2-0.45$ & 0.33 & $0.4-0.82$ & 0.72 & 7.03-20.42 & 15.32 \\
\hline & Water layer & $2.34-2.45$ & 2.37 & $0.25-0.33$ & 0.26 & $0.6-0.95$ & 0.83 & $5.01-10.78$ & 7.04 \\
\hline \multirow[t]{3}{*}{ NP } & Oil layer & $2.44-2.52$ & 2.47 & $0.09-0.45$ & 0.26 & $0.4-0.85$ & 0.66 & 23.03-92 & 57.68 \\
\hline & Oil-water layer & $2.45-2.53$ & 2.43 & $0.23-0.37$ & 0.30 & $0.4-0.8$ & 0.67 & $19.5-44.2$ & 29.38 \\
\hline & Water layer & $2.37-2.43$ & 2.39 & $0.15-0.37$ & 0.25 & $0.6-0.83$ & 0.74 & $8.7-10.13$ & 8.44 \\
\hline
\end{tabular}
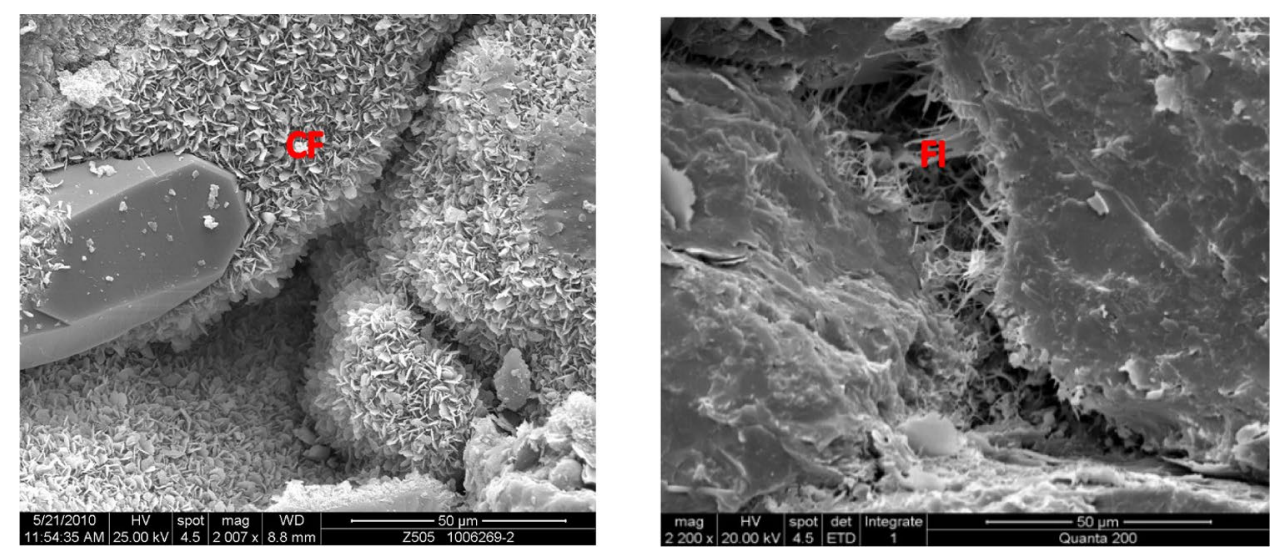

Fig. 11 Distribution of irreducible water saturation and the relationship between the irreducible water saturation and apparent resistivity increase rate, including: a irreducible water saturation distribution and $\mathbf{b}$ relationship between the irreducible water saturation and the apparent resistivity increase rate (ARI)

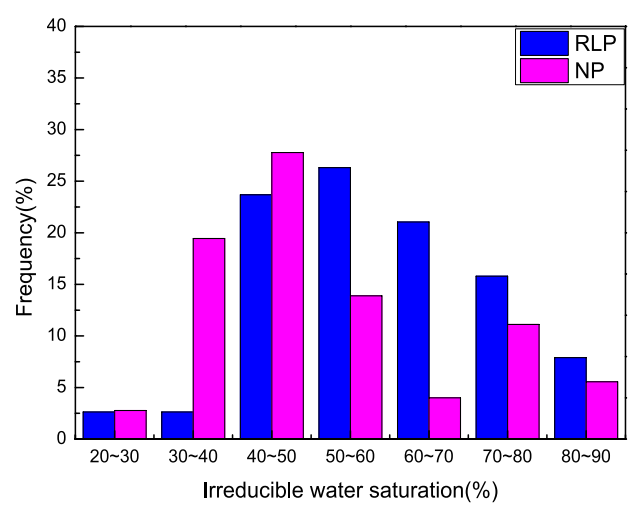

(a)

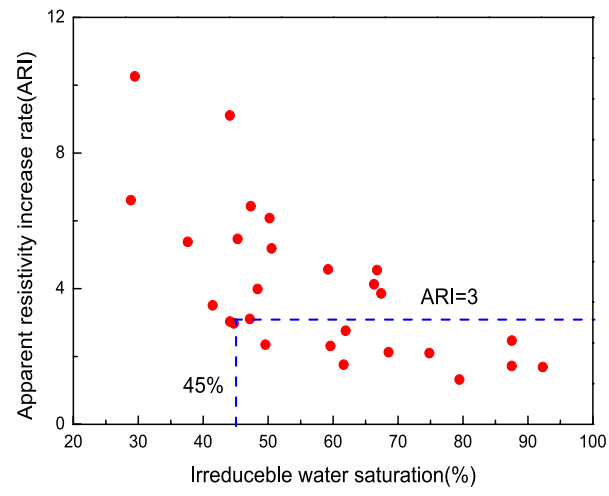

(b) 
distributed between 18,760 and $51,000 \mathrm{mg} / \mathrm{L}$ with an average value of $32,712.91 \mathrm{mg} / \mathrm{L}$. The formation water salinity in the RLP is mainly distributed between 45,950 and $88,010 \mathrm{mg} / \mathrm{L}$ with an average value of $63,462.5 \mathrm{mg} / \mathrm{L}$, and the formation water salinity in the RLP is almost twice than that of the NP. Figure 12 shows the relationship between formation water salinity and formation resistivity. It can be seen that with the increase in formation water salinity, the value of formation resistivity decreases. When the formation water salinity is greater than $45 \mathrm{~g} / \mathrm{L}$, the resistivity difference between oil-water layer and water layer is not obvious, which indicates that high salinity of formation water is an important factor to reduce the reservoir resistivity and leads to the RLP reservoir.

\section{Macro-factors: hydrocarbon expulsion capacity of source rock}

Source rocks with larger effective thickness and closer to the reservoir usually have strong hydrocarbon expulsion ability, which makes it easy to displace crude oil into small pores and form high oil saturation, vice versa (Yao et al. 2015; Shi et al. 2016). The hydrocarbon of Chang 8 reservoir mainly comes from the upper Chang 7 oil shale rock. The cross-well

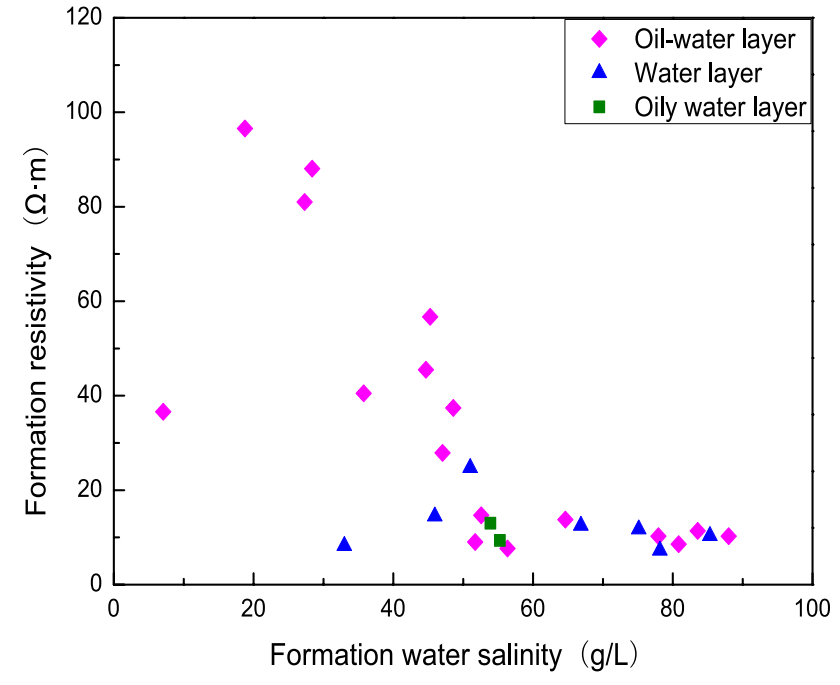

Fig. 12 The relationship between formation resistivity and formation water salinity

profiles from low resistivity constant area to high resistivity area are drawn in Fig. 13a, in which the first track of each well is depth, second track is the overlapping of acoustic and resistivity log curves to reflect source rock and the filling

Table 3 Formation water salinity statistics results

\begin{tabular}{|c|c|c|c|c|c|c|c|c|c|c|}
\hline Types & Wells & $\mathrm{K}^{+}+\mathrm{Na}^{+}(\mathrm{mg} / \mathrm{L})$ & $\mathrm{Mg}^{2+}(\mathrm{mg} / \mathrm{L})$ & $\mathrm{Ca}^{2+}(\mathrm{mg} / \mathrm{L})$ & $\mathrm{Cl}^{-}(\mathrm{mg} / \mathrm{L})$ & $\mathrm{SO}_{4}{ }^{2-}(\mathrm{mg} / \mathrm{L})$ & $\mathrm{CO}_{3}{ }^{2-}(\mathrm{mg} / \mathrm{L})$ & Type & Salinity $(\mathrm{mg} / \mathrm{L})$ & $\begin{array}{l}\text { Average } \\
(\mathrm{mg} / \mathrm{L})\end{array}$ \\
\hline \multirow[t]{11}{*}{ NP } & B2 & 10,942 & 1236 & 4074 & 25,762 & 2325 & 340 & $\mathrm{Cacl}_{2}$ & 44,680 & \multirow[t]{11}{*}{$32,712.91$} \\
\hline & M50 & 6690 & 64 & 422 & 10,583 & 505 & 496 & $\mathrm{Cacl}_{2}$ & 18,760 & \\
\hline & M93 & 9285 & 627 & 3447 & 22,017 & 0 & 380 & $\mathrm{Cacl}_{2}$ & 35,760 & \\
\hline & Z234 & 8349 & 488 & 1574 & 16,685 & 196 & 424 & $\mathrm{Cacl}_{2}$ & 27,716 & \\
\hline & M159 & 14,708 & 287 & 3500 & 28,638 & 1360 & 95 & $\mathrm{Cacl}_{2}$ & 48,590 & \\
\hline & B20 & 7971 & 517 & 1419 & 13,502 & 3401 & 499 & $\mathrm{Cacl}_{2}$ & 27,310 & \\
\hline & L146 & 4379 & 120 & 2970 & 12,026 & 237 & 262 & $\mathrm{Cacl}_{2}$ & 27,716 & \\
\hline & X259 & 7214 & 150 & 496 & 11,376 & 238 & 1525 & $\mathrm{Cacl}_{2}$ & 21,000 & \\
\hline & B53 & 3234 & 316 & 6774 & 1747 & 500 & 85 & $\mathrm{Cacl}_{2}$ & 28,380 & \\
\hline & Y435 & 5516 & 181 & 5069 & 17,671 & 211 & 250 & $\mathrm{Cacl}_{2}$ & 28,930 & \\
\hline & Z336 & 17,652 & 292 & 1463 & 28,909 & 2161 & 244 & $\mathrm{Cacl}_{2}$ & 51,000 & \\
\hline \multirow[t]{12}{*}{ RLP } & H11 & 12,693 & 6016 & 9505 & 37,493 & 22,046 & 257 & $\mathrm{Cacl}_{2}$ & 88,010 & \multirow[t]{12}{*}{$63,462.5$} \\
\hline & M92 & 21,185 & 1464 & 6204 & 44,681 & 4131 & 286 & $\mathrm{Cacl}_{2}$ & 77,950 & \\
\hline & Z386 & 18,299 & 1868 & 3762 & 39,463 & 819 & 409 & $\mathrm{Cacl}_{2}$ & 64,620 & \\
\hline & M132 & 24,599 & 724 & 5169 & 46,193 & 3573 & 580 & $\mathrm{Cacl}_{2}$ & 80,840 & \\
\hline & H12 & 15,350 & 1628 & 1789 & 27,780 & 5003 & 171 & $\mathrm{Cacl}_{2}$ & 51,720 & \\
\hline & B4 & 16,642 & 706 & 2539 & 30,850 & 1775 & 71 & $\mathrm{Cacl}_{2}$ & 52,580 & \\
\hline & M116 & 9649 & 1722 & 8702 & 32,630 & 3401 & 250 & $\mathrm{Cacl}_{2}$ & 56,350 & \\
\hline & Z251 & 11,753 & 503 & 7786 & 32,062 & 1588 & 207 & $\mathrm{Cacl}_{2}$ & 53,900 & \\
\hline & Z138 & 31,637 & 193 & 1381 & 51,122 & 0 & 466 & $\mathrm{Cacl}_{2}$ & 85,310 & \\
\hline & Z412 & 16,368 & 1245 & 3762 & 34,680 & 819 & 394 & $\mathrm{Cacl}_{2}$ & 57,270 & \\
\hline & Z113 & 12,020 & 391 & 4901 & 27,560 & 949 & 124 & $\mathrm{Cacl}_{2}$ & 45,950 & \\
\hline & M141 & 12,301 & 844 & 4175 & 26,366 & 3097 & 265 & $\mathrm{Cacl}_{2}$ & 47,050 & \\
\hline
\end{tabular}


color is black-gray, third track is geological stratification, fourth track is logging interpretation conclusion and the fifth track is natural gamma and permeability. It can be seen that the effective thickness of source rock in low resistivity reservoir area is small, and the distance between source rock and reservoir is long. Figure 13b shows the plane distribution of formation resistivity in the Huanxian area, which is located in the northwest of our study area, and the red line represents the location of cross-wells. In order to characterize the hydrocarbon expulsion capacity of source rock, we measured the distance between source rock and reservoir (D), and the effective thickness of source rock $(\mathrm{H})$ based on the cross-well profiles. Then, the hydrocarbon expulsion capacity factor $\mathrm{H} / \mathrm{D}$ was calculated by dividing $\mathrm{H}$ by $\mathrm{D}$ to reflect the hydrocarbon expulsion capacity of source rocks. The larger the H/D value, the stronger the oil filling capacity of source rocks to reservoir. Figure 13c shows the relationship between calculated $\mathrm{H} / \mathrm{D}$ and reservoir resistivity. It can be seen that with the increase of $H / D$, the reservoir resistivity increases gradually, which indicates that the development

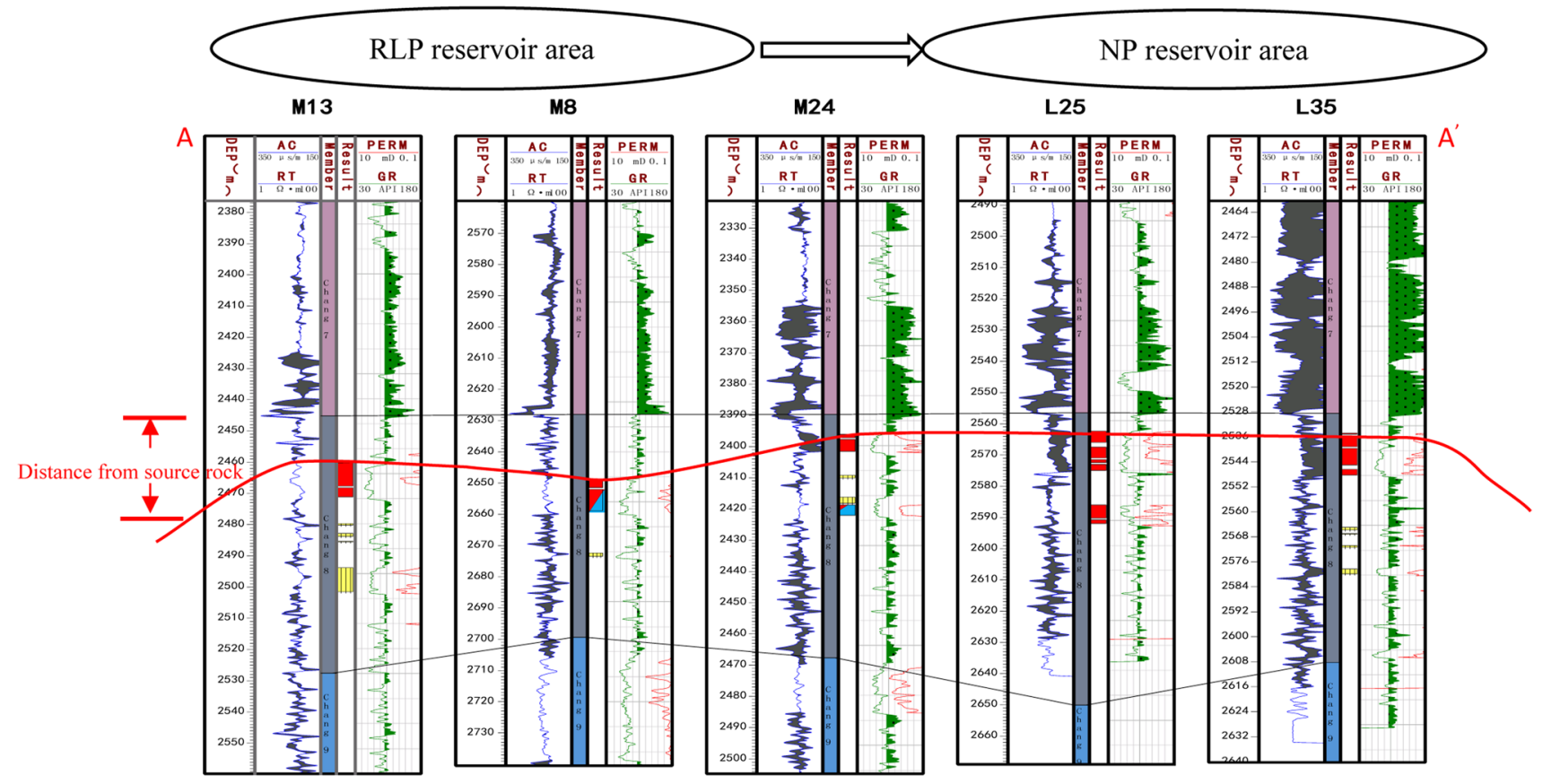

(a)

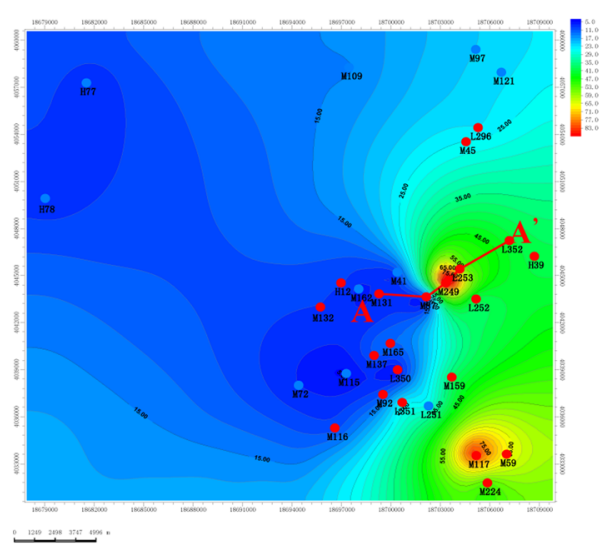

(b)

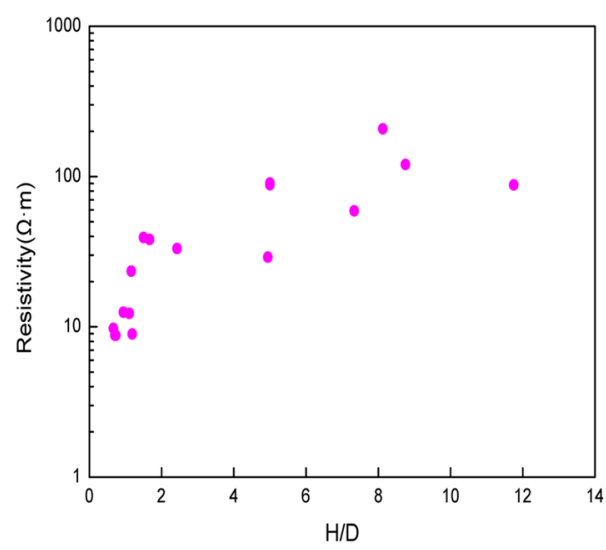

(c)
Fig. 13 The influence of hydrocarbon expulsion capacity of source rock on reservoir resistivity: a The cross-well profiles from RLP reservoir to NP reservoir, $\mathbf{b}$ the location of cross-well profiles and $\mathbf{c}$ the relationship between formation resistivity and the hydrocarbon expulsion ability factor of source rock 
of RLP reservoirs also controlled the difference of hydrocarbon expulsion ability of source rock.

\section{Macro-factors: regional difference of formation water salinity}

The plane distribution characteristics of formation resistivity and formation water salinity were compared to study the influence of regional difference of formation water salinity on reservoir resistivity. The average values of resistivity log in the test interval were used to represent the reservoir resistivity, and a plane distribution map of formation resistivity is shown in Fig. 14a. The plane distribution map of formation water salinity was plotted based on the formation water salinity analysis data (Fig. 14b). By comparing Fig. 14a and Fig. 14b, it can be seen that in the west of Huanxian area, the formation water salinity is high and the formation resistivity is low, while in the east of Huanxian area, the formation water salinity is low and the formation resistivity is high. This corresponding relationship between formation resistivity and formation water salinity shows that the distribution of RLP and NP reservoirs is also controlled by the regional difference of formation water salinity.

\section{Discussion}

According to the analysis of reservoir characteristics, the reservoir main difference between RLP and NP lies in the main types of clay minerals and pore structure. The thinfilm chlorite and filamentous illite are the most abundant clay minerals in RLP reservoirs and NP reservoirs, respectively. Although the pore structure of RLP is poorer and the micropores are more developed in RLP reservoir than NP reservoir, the average porosity and permeability are better. Previous researches have shown that the clay mineral is an important factor to affect reservoir physical properties (Durand et al. 2001; samakinde et al. 2016; Yousef et al. 2018). In general, the clay minerals filling in the pores will reduce the porosity and permeability and the pore structure becomes worse. However, if the rock matrix grains are coated by chlorite films, the intergranular porosity will be well protected due to its preventing function for quartz

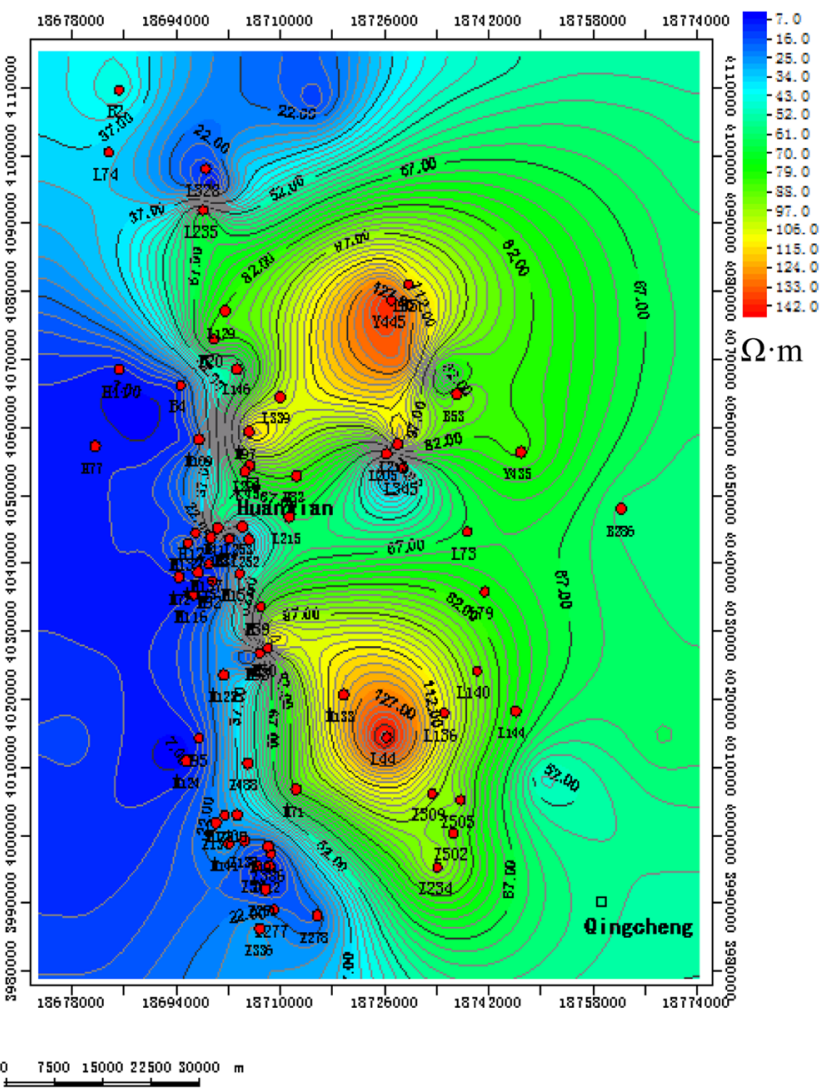

(a)

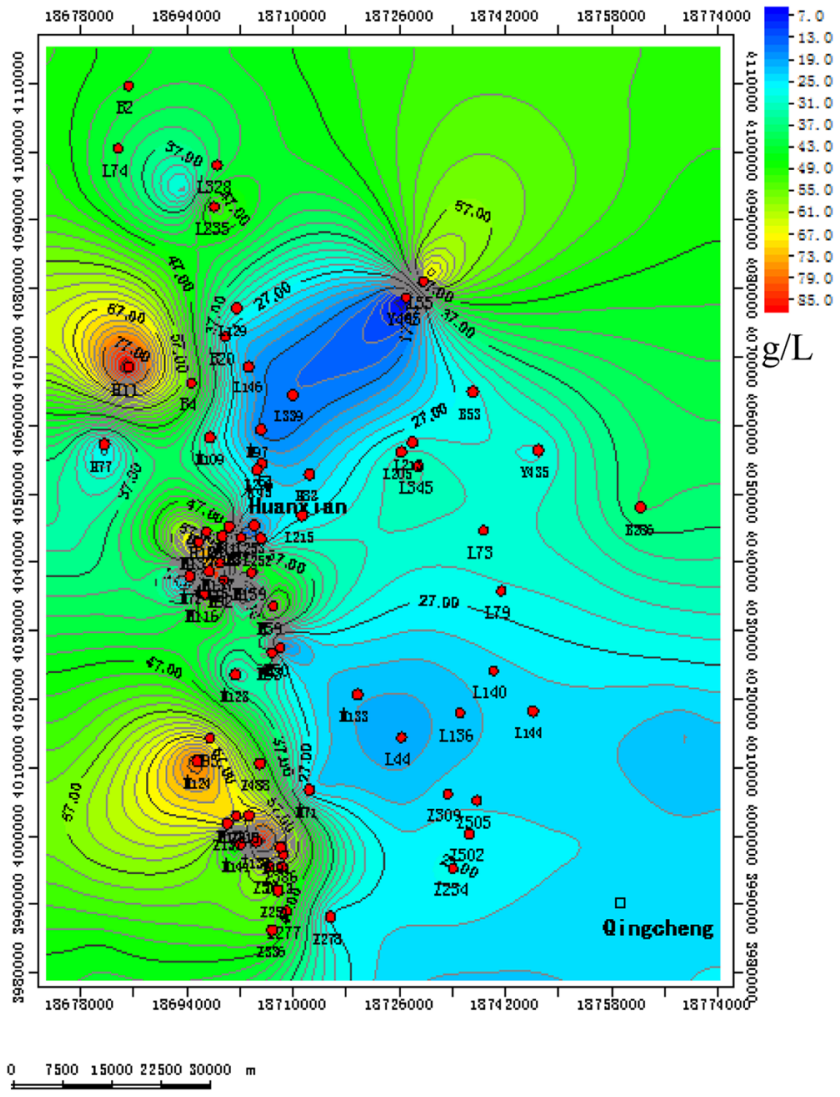

(b)

Fig. 14 Plane distribution maps of $\mathbf{a}$ formation resistivity and $\mathbf{b}$ formation water salinity, in which the red solid dots are the location of the wells 
Fig. 15 a Cross-plot of core porosity and the content of illite and chlorite and $\mathbf{b}$ cross-plot of core permeability and the content of illite and chlorite
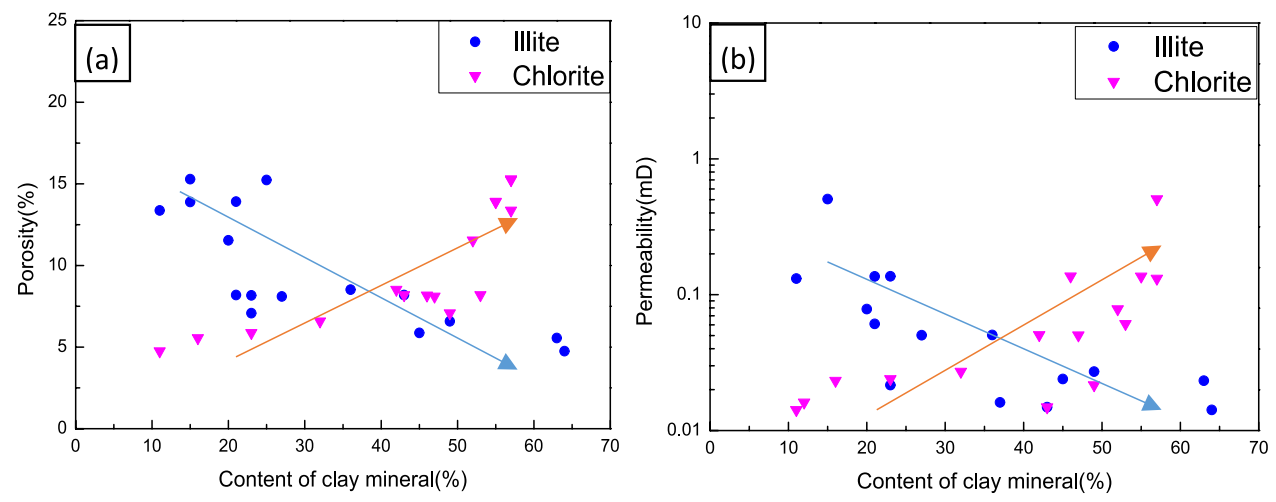

cementation (Chen et al. 2011; Stephan and Stuart, 2016; Higgs et al. 2017). In Fig. 15a, b, we plot the relationship between chlorite and illite and core porosity and permeability. It can be seen that the reservoir porosity and permeability are positively correlated with chlorite content, but negatively correlated with illite content. Therefore, it is considered that good reservoir porosity and permeability of RLP reservoir in our study area are related to the filling of a large number of thin-film chlorite in the pores.

In addition, good porosity but high content of micropores in RLP reservoir indicates that when the filling pressure of crude oil is sufficient enough, the oil-bearing reservoir with high oil saturation can be formed. However, the hydrocarbon expulsion ability of source rock in RLP reservoir is weak and pore spaces are mainly occupied by irreducible water, which makes the oil layer indicating a low oil saturation and low resistivity logging response. In addition, the difference of formation water salinity not only indicates the distribution characteristics of the RLP and NP from the macro-aspect, but also reduces the contrast of resistivity on the microaspect. The formation and distribution of RLP in our study area are controlled by the micro-factors and macro-factors together.

\section{Conclusions and suggestions}

(1) There are differences in main clay mineral types and pore structure between RLP reservoirs and NP reservoirs. Chlorite and illite are the most abundant clay minerals in RLP reservoirs and NP reservoirs, respectively. Although the porosity of RLP is better than NP, the pore space is mainly composed of micropores.

(2) The high content of micropores in RLP reservoir makes the irreducible water saturation high, together with the high formation water salinity reduced the reservoir resistivity from reservoir micro-aspect.

(3) The difference of hydrocarbon expulsion capacity of source rock as well as the regional difference of forma- tion water salinity is the macro-factors influencing the distribution of RLP and NP.

(4) It is suggested to comprehensively consider the microfactors and macro-factors during the exploration and development of oil resources in our study area.

Funding The author(s) disclosed receipt of the following financial support for the research, authorship, and/or publication of this article: This paper is sponsored by National Natural Science Foundation of China (41774144), National Major Projects "Log Interpretation and Evaluation of Complex Oil and Water Layers" (2016ZX05050), The Introduced Talent Fund of Anhui University of Science and Technology (13200427).

Open Access This article is licensed under a Creative Commons Attribution 4.0 International License, which permits use, sharing, adaptation, distribution and reproduction in any medium or format, as long as you give appropriate credit to the original author(s) and the source, provide a link to the Creative Commons licence, and indicate if changes were made. The images or other third party material in this article are included in the article's Creative Commons licence, unless indicated otherwise in a credit line to the material. If material is not included in the article's Creative Commons licence and your intended use is not permitted by statutory regulation or exceeds the permitted use, you will need to obtain permission directly from the copyright holder. To view a copy of this licence, visit http://creativecommons.org/licenses/by/4.0/.

\section{References}

Arbab B, Jahani D, Movahed B (2017) Reservoir characterization of carbonate in low resistivity pays zones in the Buwaib Formation. Persian Gulf Open Journal of Geology 7:1441-1451

Ayham A, Miho U, Andi AS, Saheed OO et al (2016) Evaluating a complex low-resistivity pay carbonate reservoir onshore Abu Dhabi: from model to implementation. In: Abu Dhabi international petroleum exhibition and conference. Society of Petroleum Engineers

Bai Z, Tan MJ, Li GR, Shi YJ (2019) Analysis of low-resistivity oil pay and fluid typing method of chang 81 member, Yanchang formation in Huanxian area, Ordos Basin, China. J Petroluem Sci Eng 175:1099-1111

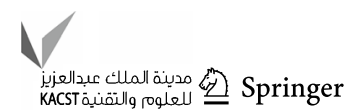


Chen GJ, Du GC, Zhang GC et al (2011) Chlorite cement and its effect on the reservoir quality of sandstones from the Panyu low-uplift. Pearl River Mouth Basin Petroleum Sci 8(2):143-150

Chu W C. Steckhan J (2011) A practical approach to determine lowresistivity pay in clastic reservoirs. SPE Annual Technical Conf. and Exhibition (Denver, Colorado, USA. 30 October-2 November 2011) SPE-147360-MS.

Claverie M Allen D F, Heaton N, Bordakov G (2010) A new look at low-resistivity and low-contrast (LRLC) pay in clastic reservoirs SPE Annual Technical Conf. and Exhibition (Florence 19-22 September 2010) SPE-134402-MS.

Durand C, Brosse E, Cerepi A (2001) Effect of pore-lining chlorite on petrophysical properties of low-resistivity sandstone reservoirs. SPE Reservoir Eval Eng 4(3):231-239

Etnyre LM, Mullarkey JC (1996) Low contrast, low resistivity reservoirs causes, pitfalls, environments of deposition. Rocky Mountain Assoc Geol. 11-16.

Feng CJ, Gingras M, Sun MS et al (2017) Logging characteristics and identification methods of low resistivity oil layer: upper cretaceous of the third member of Qingshankou formation, Daqingzijing area, Songliao Basin. China Geofluids 2017:1468-8115

Hamada GM, Al-Awad MNJ (2000) Petrophysical evaluation of low resistivity sandstone reservoirs. J Can Pet Technol 39(7):7-14

Higgs KE, Crouch EM, Raine JI (2017) An interdisciplinary approach to reservoir characterisation; an example from the early to middle Eocene Kaimiro formation, Taranaki Basin. New Zealand Marine and Petroleum Geol 86:111-139

Kibria G, Hossain M (2012) Investigation of geotechnical parameters affecting electrical resistivity of compacted clays. J Geotec Geoenviron Eng 138(12):1520-1529

Kumar P, Solomon R, Varun TR, Samanta A (2009) An integrated approach to solve reverse resistivity contrast problem in fresh water shaly sand reservoir of changmaigaon field, Assam India A case Ssudy. 2nd SPWLA-India Symposium, November 19-20.

Kusuma DP, Halim A, Audinno RT, Pratama IP (2016) Integrated analysis of the low resistivity hydrocarbon reservoir in the " $\mathrm{S}$ " Field. Indonesian Petroleum Association, Fortieth Annual Convention \& Exhibition.

Mao KY (2016) Logs fluid typing methods and adaptive analysis of tight sandstone reservoir of Yingcheng formation in Lishu Fault. Adv Earth Sci 31(10):1056-1066

Mao ZQ, Kuang LC, Xiao CW et al (2007) Identification and evaluation of low resistivity pay zones by well logs and the petrophysical research in China. Pet Sci 4(1):41-48

Montaron B (2007) A quantitative model for the effect of wettability on the conductivity of porous rocks. 15th SPE Middle East Oil \& Gas Show and Conference, Bahrain.

Onyinye EM (2010) Recognition, causes, and evaluation of low resistivity pay sands using wireling logs: a case study of "AMO-field" within the greater ughelli depobelt of the Tertiary Niger Delta Basin. University of Nigeria, Nsukka

Ouyang J, Mao ZQ, Xiu LJ (2009) Genetic mechanism for low contrast hydrocarbon bearing reservoirs and well log evaluation method. Petroleum Industry Press, Beijing, pp 1-357

Pratama E, Ismail MS, Ridha S (2017) An integrated workflow to characterize and evaluate low resistivity pay and its phenomenon in a sandstone reservoir. J Geophys Eng 14(3):513-519

Qin Z, Hou M, Wang ZH et al (2013) Logging fluid identification method of low resistivity contrast reservoir invaded by fresh water mud-a case study of well block YD in erdos basin. Appl Mech Mater 318:442-446

Samakinde C, Opuwari M, Donker JMV (2016) The effect of clay diagenesis on petrophysical properties of the lower cretaceous sandstone reservoirs, Orange Basin, South Africa. S Afr J Geol 119(1):187-202

Shi YJ, Li GR, Zhou JY et al (2016) Filling mode and corresponding log interpretation method for low permeability-tight reservoirs in Yanchang group, Mesozoic. Ordos Basin Well Logging Technology 40(2):202-208

Stephan S, Stuart JJ (2016) Enhanced porosity preservation by pore fluid overpressure and chlorite grain coatings in the Triassic Skagerrak, Central Graben, North Sea, UK. Geol Soc, London, Special Public 435:321-341

Tan GH (2020) Analysis on log response characteristics of oil shale and in-situ mining geological evaluation in Qingshankou formation of South of Songliao Basin. IOP Conference Series: Earth and Environmental Science. https://doi.org/10.1088/1755-1315/ 514/2/022080.

William AT, Mshah BI, Astia AH et al (2016) Low-resistivity pay evaluation, case study: thin bed sand-shale lamination reservoirs, Peninsula, Malay Basin. International Petroleum Technology Conference, 14-16 November, Bangkok, Thailand.

Worthington PF (2000) Recognition and evaluation of low-resistivity pay. Pet Geosci 6:77-92

Xiao L, Mao ZQ, Dou WT et al (2012) Types and genesis of low contrast hydrocarbon reservoirs in low permeability sandstones. Special Oil Gas Reserv 19(1):42-46

Xie RH, Feng QN, Gao J et al (2002) Mechanisms of petrophysical parameter change in oil and gas reservoirs of low resistivity. Chin J Geophys 45(1):132-140

Yan L, Tan SQ, Pan BZ et al (2010) Genetic mechanism and logging evaluation method for low resistivity reservoirs: Taking Guantao Formation of Gangbei area for instance. J Jilin Univ (earth Science Edition) 40(6):1456-1462

Yan WC, Sun JM, Zhang JY et al (2018) Studies of electrical properties of low-resistivity sandstones based on digital rock technology. J Geophy Eng 15(1):153-163

Yang CM, Zhou CC, Cheng XZ (2008) Origin of low resistivity pays and forecasting of favorable prospecting areas. Pet Explor Dev 35(5):600-605

Yao JL, Zhao YD, Deng XQ et al (2015) Controlling factors of tight oil reservoir in Triassic Yanchang formation in Ordos Basin. J Jilin Univ (Earth Science Edition) 45(4):983-992

Yousef I, Sudakov V, Morozov V et al (2018) Diagenetic clay minerals and reservoir quality of the upper triassic sandstone in euphrates graben, East of Syria(Conference Paper). Int Multidiscip Sci Geoconf Surv Geold Mining Ecol Management, SGEM 18(1):397-404

Zemanek J (1989) Low-resistivity hydrocarbon-bearing sand reservoirs. SPE Form Eval 4(4):515-521

Zhang SH, Shi YJ, Chen G et al (2018) Identification methods and water productivity classification evaluation of low contrast chang 61 oil reservoirs in Jiyuan area. Ordos Basin China Petroleum Exploration 23(1):71-80

Publisher's Note Springer Nature remains neutral with regard to jurisdictional claims in published maps and institutional affiliations. 